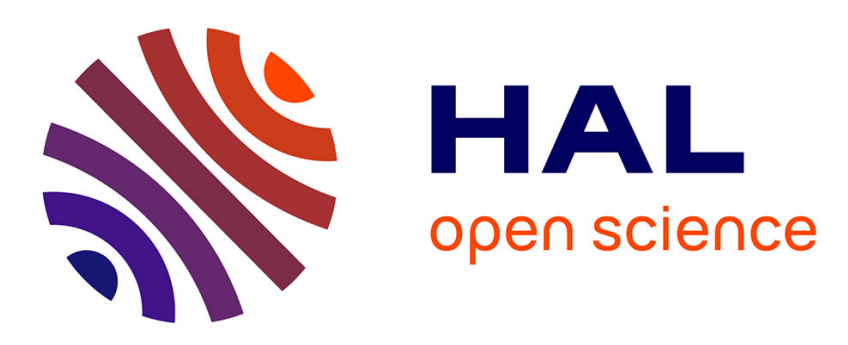

\title{
The rise and rise of stealth nanocarriers for cancer therapy: passive versus active targeting
}

Ngoc Trinh Huynh, Emilie Roger, Nolwenn Lautram, Jean-Pierre Benoît, Catherine Passirani-Malleret

\section{- To cite this version:}

Ngoc Trinh Huynh, Emilie Roger, Nolwenn Lautram, Jean-Pierre Benoît, Catherine PassiraniMalleret. The rise and rise of stealth nanocarriers for cancer therapy: passive versus active targeting. Nanomedicine, 2010, 5 (9), pp.1415-33. 10.2217/nnm.10.113 . hal-03171842

\section{HAL Id: hal-03171842 \\ https://univ-angers.hal.science/hal-03171842}

Submitted on 17 Mar 2021

HAL is a multi-disciplinary open access archive for the deposit and dissemination of scientific research documents, whether they are published or not. The documents may come from teaching and research institutions in France or abroad, or from public or private research centers.
L'archive ouverte pluridisciplinaire HAL, est destinée au dépôt et à la diffusion de documents scientifiques de niveau recherche, publiés ou non, émanant des établissements d'enseignement et de recherche français ou étrangers, des laboratoires publics ou privés. 


\section{The rise and rise of stealth nanocarriers for cancer therapy: passive versus active targeting}

Over the past few decades, interest in designing and developing nanosized drug delivery systems (also known as nanocarriers) has undergone considerable explosion. Indeed, these nanocarriers provide potential solutions to improve cancer chemotherapy by over-riding the poor biopharmaceutical properties of drugs, and by altering the pharmacokinetic and biodistribution of conventional cytotoxic molecules [1]. However, the pharmaceutical application of these systems in systemic administration is usually limited, owing to their rapid elimination from the blood circulation, resulting from a nonspecific uptake by the mononuclear phagocyte system (MPS) $[2,3]$. Consequently, in order to overcome the opsonization of nanocarriers, a number of widely used and effective methods have been investigated to render nanocarriers 'invisible' to the immune system, creating long-circulating nanoparticles (NPs), known as stealth NPs. Interestingly, by coating the nanoparticulate surface with poly(ethylene glycol) (PEG), referred to as a PEGylation process, NPs exhibited decreased levels of uptake by the MPS and, consequently, an increased circulation time in the blood, allowing passive targeting of the tumors [2,4]. Furthermore, surface modification of NPs with PEG moieties has emerged as a platform for the incorporation of active-targeting ligands, thereby providing the drug carriers with specific tumor-targeting properties [5].

In this article, the interest of stealth NPs will be described. Nanocarriers that will be considered include liposomes (vesicles in which an aqueous volume is entirely surrounded by a bilayer phospholipid membrane), micelles (self-assembly of amphiphiles that form supramolecular core-shell structures in the aqueous environment), polymer NPs (including nanospheres and nanocapsules) and lipid NPs (a biocompatible lipid core that is present under solid matrix [i.e., solid lipid NPs], or a lie 
further growth and enlargement, tumors need to form new blood vessels, via the angiogenesis process, in order to obtain nutrients and sustain their growth [4]. Tumor vessels are generally abnormal, and have aberrant branching, blind loops of twisted shape, which are characterized by architectural defectiveness, and a high degree of vascular density [10]. When compared with normal vessels, tumor vessels are 'leaky', owing to basement membrane abnormalities and a decreased number of pericytes lining the rapidly proliferating endothelial cells [11]. This results in an enhanced permeability for molecule passage through the microvascular wall into the interstitium surrounding tumor cells [12]. Indeed, the pore size of tumor vessels varies from $100 \mathrm{~nm}$ to almost $1 \mu \mathrm{m}$ in diameter, depending upon the anatomic location of the tumors (e.g., smaller in cranial tumors compared with subcutaneous tumors) and the tumor growth (e.g., smaller in regressing tumors) [13]. In comparison, the tight endothelial junctions of normal vessels are typically of 5-10 $\mathrm{nm}$ in size [13].

Moreover, solid tumors are also characterized by an impaired lymphatic network [4]. Lymphatic vessels are widely distributed throughout the body, whose major function is to return the interstitial fluid to the blood circulation. Normally, macromolecules are cleared from tissues via the lymphatic system. However, owing to the lack of lymphatic drainage, the clearance of macromolecules from solid tumors is eventually decreased and, consequently, they can have extended retention times in the tumor interstitium [14]. This, together with leaky tumor blood vessels, results in the enhanced permeability and retention (EPR) effect [4]. Therefore, passive cancer targeting is obtained through the accumulation of long-circulating nanocarriers, at a higher concentration in the tumors than in the plasma or in other tissues (Figure 2).

To achieve selective tumor accumulation via the EPR effect, NPs must reside for long enough in the bloodstream to provide a sufficient level of target accumulation. Unfortunately, following intravenous administration, conventional nanocarriers (first generation) have short circulation half-lives, resulting from their opsonization and interaction with the MPS. The opsonization process consists of the adsorption of protein entities, which interact with specific plasma membrane receptors on monocytes and various subsets of tissue macrophages, thus promoting particle recognition and elimination from the systemic circulation by MPS cells, mainly Kupffer cells of the liver and macrophages of the spleen [2]. This premature elimination prevents first-generation nanocarriers from reaching tumor sites by the EPR effect. Consequently, particulate surfaces must be modified for the purpose of evading the opsonization process, and the uptake by MPS cells [15]. Thus, second generation of long-circulating nanocarriers is based on the physico 
discussed by Vonarbourg et al. [16]. Briefly, preferentially NPs should be small $(<200 \mathrm{~nm})$, composed of biocompatible compounds and present a neutral and hydrophilic surface, with a dense and flexible coating of a polymer or polysaccharide [16]. As shown in Table 1, the technology of PEGylation has been successfully applied to various types of NPs. The pioneering publications on PEG liposomes were published at the end of the 1980s by Allen et al. [21] and the cellspecific targeting of liposomes even before, in 1980 [22,23].

In this article, our discussions will be limited to the NPs whose surfaces have been modified with PEG, the most widely used material for surface modification because it is nontoxic, nonimmunogenic and approved by the US FDA for oral and parenteral applications in humans.

\section{- Anticancer drugs loaded in stealth NPs: from animal studies to clinical trials in humans}

According to the properties of anticancer drugs, the sites of interest, and the scientific and economic constraints (e.g., patents, cost of materials and final products, and scaling-up of the production processes), appropriate NPs have to be optimized. Many in vivo studies of stealth NPs for cancer therapy have been performed in this way, and are summarized in Table 2. Among them, several formulations of drug-loaded stealth NPs were approved by the FDA for clinical studies, but few of them are currently on the market (TaвLE 3). The following chapter focuses on some of the clinical studies using PEGylated NPs loaded with various anticancer agents, classified by function of their drug family. Moreover, passive and active targeting strategies were grouped in TABLES $2 \& 3$ in order to facilitate their comparison.

\section{Taxanes}

One of the most successful cancer drugs, paclitaxel (PTX), has shown its potency against a broad spectrum of cancers, including breast, ovarian, and small-cell and non-small-cell lung cancers [24]. Another used taxane anticancer agent is docetaxel (DTX). Owing to their high hydrophobicity (aqueous solubility is 0.7 and 6-7 $\mu \mathrm{g} / \mathrm{ml}$ for PTX and DTX, respectively), special formulations were prepared for intravenous administration. PTX formulations (e.g., Taxol $^{\circledR}$ and Paxen ${ }^{\circledR}$ ) consist of a mixture of absolute alcohol and Cremophor EL ${ }^{\circledR}$; DTX $\left(\right.$ Taxotere $^{\circledR}$ ) is present as a concentrated viscous solution in polysorbate 80 (Tween $\left.^{\circledR} 80\right)$. However, toxicological side effects of these current commercial formulations of taxanes were observed, owing to the presence of these excipients $[25,26]$. Consequently, the clinical use of both formulations is recommended, in association with premedication with corticosteroids and $\mathrm{H} 1 / \mathrm{H} 2$ antihistamines (for PTX) to minimize the side effects [24].

Therefore, many strategies to design alternative formulations, for both PTX and DTX, have been under investigation. Among potential approaches to achieve a desired formulation by various methods (e.g., cosolvency, emulsification, micellization, local drug delivery devices [e.g., pastes and implants]) [27], nanotechnology offers a promising solution for chemotherapy with taxanes. Recently, Abraxane ${ }^{\circledR}$, an albuminbound NP formulation of PTX, was granted FDA approval in January 2005. Such drug-conjugated albumin formulations are also considered as an attractive approach for selective drug targeting by improving the pharmacokinetic profile of anticancer agents, owing to the long

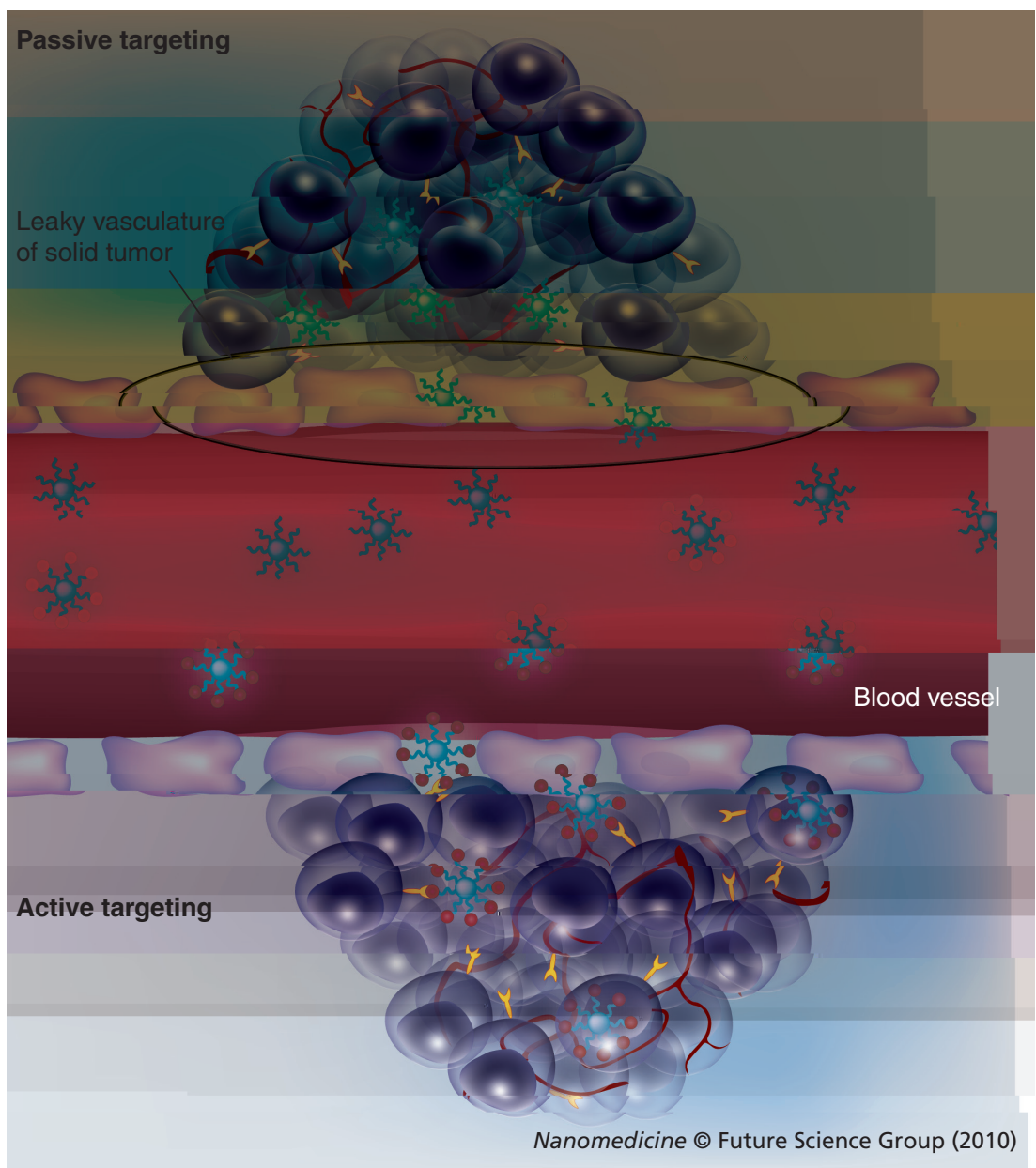

Figure 2. Passive targeting and active targeting for drug delivery to solid tumors. 
Table 1. Various coatings used for the preparation of stealth nanoparticles.

\begin{tabular}{|c|c|c|c|}
\hline Group & Coating & Type of NP & Ref. \\
\hline PEG & PEG & & {$[137]$} \\
\hline \multirow[t]{3}{*}{ PEG-lipid conjugates } & DSPE-PEG & $\begin{array}{l}\text { Liposomes } \\
\text { LNCs }\end{array}$ & $\begin{array}{r}{[51,60,61,138-141]} \\
{[6,142,143]}\end{array}$ \\
\hline & DPPE-PEG & $\begin{array}{l}\text { Liposomes } \\
\text { SLNs }\end{array}$ & $\begin{array}{r}{[144]} \\
{[145]}\end{array}$ \\
\hline & Acid stearic PEG & $\begin{array}{l}\text { SLNs } \\
\text { LNCS }\end{array}$ & $\begin{array}{r}{[91,145-147]} \\
{[148]}\end{array}$ \\
\hline \multirow[t]{8}{*}{ Block copolymers } & PEG-PLA & $\begin{array}{l}\text { Polymer NPs } \\
\text { Micelles }\end{array}$ & $\begin{array}{r}{[149-153]} \\
{[30,154]}\end{array}$ \\
\hline & PEG-PCL (poly-e-caprolactone) & Polymer NPs & [155] \\
\hline & PEG-PLGA & Polymer NPs & [155-162] \\
\hline & PEG-poly(hexadecylcyanoacrylate) & Polymer NPs & [163-168] \\
\hline & PCL-PEG-PCL & Polymer NPs & [169-171] \\
\hline & PLA-PEG-PLA & Polymer NPs & {$[172-174]$} \\
\hline & PEG-PLA-PEG & Polymer NPs & {$[78,152,174]$} \\
\hline & Poloxamer $^{\circledR} /$ Poloxamine $^{\circledR}$ & $\begin{array}{l}\text { Polymer micelles } \\
\text { Polymer NPs }\end{array}$ & $\begin{array}{r}{[44]} \\
{[150,151,175]}\end{array}$ \\
\hline \multirow[t]{3}{*}{ Other polymers } & Poly(amino acid) & & {$[88,176]$} \\
\hline & Oxazoline-derived polymers & & {$[177]$} \\
\hline & Polyvinyl pyrrolidone & & {$[178,179]$} \\
\hline \multirow[t]{3}{*}{ Polysaccharides } & Chitosan & & {$[77,180,181]$} \\
\hline & Dextran & & {$[72,182,183]$} \\
\hline & Heparin & & {$[72,181,183]$} \\
\hline
\end{tabular}

half-life of albumin in the body $[28,29]$. However, we do not discuss this in detail because their surfaces were not coated with PEG to confer the stealth properties.

Another example of a Cremophor-free formulation of PTX is Genexol ${ }^{\circledR}$-PM, a polymer micellar system prepared with methoxy-PEGpoly(lactide) (mPEG-PLA)-block copolymers. In vivo studies on mice, following intravenous injection, demonstrated considerable accumulation of Genexol-PM in subcutaneously implanted B16 melanoma tumor, and a significant antitumor effect against SKOV-3 human ovarian cancer and MX-1 human breast cancer when compared with Taxol [30]. In a Phase I study, in which patients received Genexol-PM intravenously without premedication for $3 \mathrm{~h}$ once every 3 weeks, the maximum tolerated dosage (MTD) of $390 \mathrm{mg} / \mathrm{m}^{2}$ was obtained [31]. The main dose-limiting toxicities of Genexol-PM were neuropathy, myalgia and neutropenia, with an absence of acute hypersensitivity reactions. The Phase II trials showed that Genexol-PM was tolerated and effective in patients with advanced pancreatic cancer [32], metastatic breast cancer [33], and also in patients with advanced non-small-cell cancer who were administered a combination of Genexol-PM and cisplatin [34]. Genexol-PM is now approved in South Korea [35], and is undergoing Phase III and IV trials in patients with recurrent or metastatic breast cancer [301].

\section{Anthracyclines: doxorubicin/ daunorubicin}

Anthracyclines, including doxorubicin (DOX) and daunorubicin, are among the most active agents available for the treatment of breast cancer, and are a key component of adjuvant therapy regimens. However, the clinical use of these agents is always limited, particularly in patients receiving adjuvant treatment with anthracyclines during the early phases of breast cancer, owing to their cumulative dose-related cardiotoxicity [36]. Therefore, it is necessary to exploit drug delivery systems to confer altered biodistribution and drug-release properties to minimize cardiotoxicity and maximize drug delivery to tumor tissues.

One striking success of DOX-loaded stealth NPs is the case of Doxil ${ }^{\circledR}$ (in the USA) or Caelyx $^{\circledR}$ (in Europe) in 1995, which was the first nanocarrier approved by the US FDA and the European Medicines Agency (EMA) for cancer therapeutics. This is a DOX-containing formulation based on stealth liposomes, which, 


\section{Table 2. Preclinical studies using stealth nanoparticles in cancer chemotherapy.}

\begin{tabular}{|c|c|c|c|c|}
\hline Stealth NPs & $\begin{array}{l}\text { Targeting } \\
\text { type }\end{array}$ & Animal & Findings & Ref. \\
\hline \multicolumn{5}{|l|}{ Paclitaxel } \\
\hline $\begin{array}{l}\text { DSPE-mPEG2000- } \\
\text { liposomes }\end{array}$ & Passive & $\begin{array}{l}\text { Rat, } \\
\text { nude } \\
\text { mouse }\end{array}$ & $\begin{array}{l}\mathrm{T}_{1 / 2 \beta}=17.8 \text { vs } 5.05 \mathrm{~h} \text { for uncoated liposomes, and } 1.65 \mathrm{~h} \text { for Taxol }{ }^{\circledR} \text { in } \\
\text { rats. Enhanced antitumor effect due to high accumulation in MDA- } \\
\text { MB-231 human breast cancer bearing nude mice. High PTX payload with } \\
\text { an efficiency level up to } 70 \%\end{array}$ & [139] \\
\hline $\begin{array}{l}\text { Anti-HER2- } \\
\mathrm{S}_{100} P C: C H O L: m P E G 2000- \\
\text { DSPE:Mal-PEG2000-DSPE } \\
\text { liposomes }\end{array}$ & Active & $\begin{array}{l}\text { Nude } \\
\text { mouse }\end{array}$ & $\begin{array}{l}\text { Higher ratio of tumor to plasma drug concentrations (T/P ratio) than } \\
\text { nontargeted liposomes in HER2-overexpressing breast carcinoma model } \\
\text { (BT-474) linked to a higher antitumor efficacy. Weak T/P ratio in low } \\
\text { HER2-expressing model (MDA-MB-231) }\end{array}$ & [184] \\
\hline $\begin{array}{l}\text { DPPE-mPEG5000 } \\
\text { liposomes }\end{array}$ & Passive & Mouse & $\begin{array}{l}\text { Long circulation time ( } \mathrm{T}_{1 / 2 \beta}=48.6 \mathrm{~h} \text { vs } 9.27 \mathrm{~h} \text { for uncoated liposomes). } \\
\text { Considerable decrease in drug uptake in MPS-containing organs (liver } \\
\text { and spleen) at } 0.5 \text { and } 3 \mathrm{~h} \text { after injection as compared with the } \\
\text { conventional liposomes }\end{array}$ & {$[144]$} \\
\hline mPEG-PLA NPs & Passive & Rat & $\begin{array}{l}\text { Higher half-life }(18.80 \pm 3.14 \mathrm{~h}) \text { and AUC than Taxol }(2.75 \text { - and } \\
\text { 3.09-times, respectively) at the same dose of } 10 \mathrm{mg} / \mathrm{kg} \text {. Drug } \\
\text { encapsulation efficiency up to } 87 \%\end{array}$ & {$[153]$} \\
\hline PLA-PEG-RGD micelles & Active & $\begin{array}{l}\text { Nude } \\
\text { mouse }\end{array}$ & $\begin{array}{l}\text { Higher tumor accumulation than nontargeted micelles in a model } \\
\text { of MDA-MB- } 435 \text { breast tumor linked to a tumor regression with } \\
\text { PTX-targeted micelles }\end{array}$ & {$[185]$} \\
\hline PEG-PLGA NPS & Passive & Mouse & $\begin{array}{l}\text { Remarkable tumor growth inhibition and increased survival rate of } \\
\text { transplantable liver tumor-bearing mice compared with Taxol }\end{array}$ & {$[160]$} \\
\hline \multicolumn{5}{|l|}{ Docetaxel } \\
\hline PEG-PLGA NPS & Passive & Mouse & $\begin{array}{l}\text { Drug biological half-life increased and tumor accumulation five-times } \\
\text { higher than Taxotere }{ }^{\circledR} \text { on C } 26 \text { tumor-bearing mice }\end{array}$ & {$[161]$} \\
\hline DSPE-mPEG2000 LNCs & Passive & Mouse & Long circulation time (half-life: 1.4 vs $0.3 \mathrm{~h}$ for Taxotere) & [143] \\
\hline \multicolumn{5}{|l|}{ Doxorubicin } \\
\hline $\begin{array}{l}\text { Anti-HER2-DSPE-COOH- } \\
\text { PEG2000 liposomes }\end{array}$ & Active & $\begin{array}{l}\text { Rat, } \\
\text { nude } \\
\text { mouse }\end{array}$ & $\begin{array}{l}\text { Long circulation time of immunoliposomes and PEGylated liposomes in } \\
\text { normal rats. Increased antitumor efficacy and reduced systemic toxicity } \\
\text { with DOX anti-HER2 immunoliposomes. Similar levels of tumor tissue } \\
\text { accumulation in a nude mouse model of HER2-overexpressing breast } \\
\text { cancer (BT-474) for both targeted and nontargeted liposomes }\end{array}$ & {$[106,107]$} \\
\hline $\begin{array}{l}\text { DSPE-PEG-maleimide- } \\
\text { RGD liposomes }\end{array}$ & Active & Mouse & $\begin{array}{l}\text { Specific interaction with tumor vasculature (intravital microscopy), not } \\
\text { observed for nontargeted PEGylated liposomes. Inhibition of tumor } \\
\text { growth in a doxorubicin-insensitive murine C } 26 \text { colon carcinoma model } \\
\text { by DOX RGD-immunoliposomes. No growth deceleration with DOX } \\
\text { nontargeted liposomes }\end{array}$ & [121] \\
\hline $\begin{array}{l}\text { SPC:CHOL:DSPE- } \\
\text { PEG:DSPE-PEG-RGD } \\
\text { liposomes }\end{array}$ & Active & $\begin{array}{l}\text { Nude } \\
\text { mouse }\end{array}$ & $\begin{array}{l}\text { Similar drug accumulation in tumors in a model of murine B16 melanoma } \\
\text { between targeted and nontargeted liposomes. Higher antitumor effect } \\
\text { for DOX immunoliposomes than nontargeted liposomes }\end{array}$ & {$[186,187]$} \\
\hline $\begin{array}{l}\text { Folate-targeted PEGylated } \\
\text { liposomes }\end{array}$ & Active & Mouse & $\begin{array}{l}\text { Similar tumor accumulation between targeted and nontargeted } \\
\text { liposomes in BALB/C mice with high folate receptor-expressing tumors } \\
\text { (mouse } \mathrm{M109,} \text { human KB carcinomas) }\end{array}$ & [188] \\
\hline $\begin{array}{l}\text { mAb 2C5-modified } \\
\text { PEGylated liposomes (mAb } \\
\left.\text { 2C5-modified Doxil }{ }^{\circledR}\right)\end{array}$ & Active & $\begin{array}{l}\text { Nude } \\
\text { mouse }\end{array}$ & $\begin{array}{l}\text { Significant therapeutic benefit showing substantial decrease of tumor size } \\
\text { and doubling of survival time provided by } 2 \mathrm{C} 5 \text {-immunoliposomes in } \\
\text { intracranial U-87 MG brain tumors in nude mice over control formulations }\end{array}$ & [103] \\
\hline PEG-PLGA NPS & Passive & Mouse & $\begin{array}{l}\text { Remaining } 40 \% \text { injected dose in the serum of BALB/c mice } 24 \mathrm{~h} \\
\text { postinjection. Decrease in cardiotoxicity }\end{array}$ & {$[156]$} \\
\hline PCL-PEG-PCL NPS & Passive & Mouse & Significant antitumor effect on a subcutaneous C-26 tumor & {$[171]$} \\
\hline Folate-PLGA-PEG micelles & Active & $\begin{array}{l}\text { Nude } \\
\text { mouse }\end{array}$ & $\begin{array}{l}\text { Higher drug concentration in tumor and higher antitumor effect than } \\
\text { nontargeted micelles in a model of KB human squamous cell carcinoma }\end{array}$ & [189] \\
\hline
\end{tabular}




\section{Table 2. Preclinical studies using stealth nanoparticles in cancer chemotherapy.}

\begin{tabular}{|c|c|c|c|c|}
\hline Stealth NPs & $\begin{array}{l}\text { Targeting } \\
\text { type }\end{array}$ & Animal & Findings & Ref. \\
\hline \multicolumn{5}{|l|}{ Doxorubicin (cont.) } \\
\hline Stearic acid-PEG2000 SLNs & Passive & $\begin{array}{l}\text { Rat, } \\
\text { rabbit }\end{array}$ & $\begin{array}{l}\text { Higher half-life time and plasma AUC, decrease of the DOX heart } \\
\text { concentration compared with free-drug commercial solution. } \\
\text { Highest concentration of DOX in the blood obtained with the highest } \\
\text { concentration of stealth agent }\end{array}$ & {$[91,146]$} \\
\hline Glycol chitosan NPs & Passive & Mouse & $\begin{array}{l}\text { Amount of NPs gradually increased in tumor as blood circulation time } \\
\text { increased. Concentration in blood } 14 \% \text { of dose at } 1 \text { day, and } 8 \% 3 \text { days } \\
\text { after intravenous injection. DOX-glycol chitosan NPs exhibited lower } \\
\text { toxicity but comparable antitumor activity to free DOX }\end{array}$ & [190] \\
\hline \multicolumn{5}{|l|}{ Cisplatin } \\
\hline mPEG-PLGA NPs & Passive & Mouse & $\begin{array}{l}\text { Decrease of tumor volume and higher survival rate in HT- } 29 \text { tumor- } \\
\text { bearing SCID mice than free drug, and good tolerance by normal } \\
\text { BALB/C mice }\end{array}$ & {$[155]$} \\
\hline \multicolumn{5}{|l|}{ Camptothecin analogs } \\
\hline $\begin{array}{l}\text { 10-Hydroxycamptothecin- } \\
\text { loaded PCL-LA-PEG-PCL- } \\
\text { LA NPS }\end{array}$ & Passive & Mouse & $\begin{array}{l}\text { Superior antitumor effect and extended retention time in the blood of } \\
\mathrm{S}-180 \text { (murine sarcoma)-bearing mice }(>22 \mathrm{ng} / \mathrm{ml} \text { detected at } 24 \mathrm{~h} \\
\text { postinjection, whereas free drug injection was undetectable) }\end{array}$ & {$[169,170]$} \\
\hline $\begin{array}{l}\text { Topotecan loaded } \\
\text { anti-HER2 and anti-EGF } \\
\text { receptor liposomes }\end{array}$ & Active & Mouse & $\begin{array}{l}\text { Improved antitumor activity against HER2-overexpressing human breast } \\
\text { cancer (BT474) xenografts }\end{array}$ & [191] \\
\hline \multicolumn{5}{|c|}{ 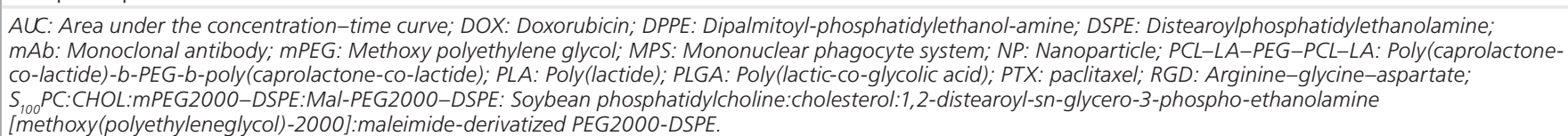 } \\
\hline
\end{tabular}

consequently, has been approved for AIDSrelated Kaposi's sarcoma, and is now commercially available for the treatment of metastatic breast cancer, advanced ovarian cancer and multiple myeloma [37,38]. Preclinical and clinical studies have shown that Doxil preferentially accumulated in tumor xenografts and human tumors, resulting in an enhancement of drug concentration in the tumor compared with free DOX [39]. The plasma area under the concentration-time curve (AUC) was at least 60 -fold higher in animals, and approximately 300 -fold higher in humans, than free DOX. Doxil toxicity is characterized by dominant and doselimiting mucocutaneous toxicities (stomatitis, hand-foot syndrome or palmar-planta erythrodysesthesia [40]), mild myelosupression and minimal alopecia, but no apparent cardiac toxicity [41]. The reduced cardiotoxicity allows a larger cumulative dose than that acceptable for free DOX. Therefore, Doxil can be effectively and safely substituted for conventional DOX, allowing retreatment with an anthracycline in the metastatic setting [42].

Other nanoparticulate systems have also been investigated to encapsulate DOX. SP1049C, a micellar formulation containing DOX and two nonionic block copolymers, Pluronic ${ }^{\circledR}$ L-61 and
Pluronic ${ }^{\circledR}$ F-127, can be used for the treatment of primary and relapsed tumors. First, in preclinical studies, SP1049C (micellar DOX) demonstrated higher antifnor activi y than free DOX in DOX-resistant tumors and in mlti drug-resistance (MDR) cells [43,44]. The authors explained this higher activity of micellar DOX, in comparison with free DOX, by mechanistic hypotheses: the micellar formulation increases the drug uptake; Pluronic L-61 (one of the two copolymers sed $\mathrm{n}$ he ormulation) nhibits P-glycoprotein efflx, which normally limits the free-drug uptake and, consequently, micellar formulation increases the drug uptake; and, finally, the micellar formulation changes the intracellular drug trafficking. Then, in the Phase I study, the pharmacokinetic profile of SP1049C showed a slower clearance than free DOX [45]. The principal dose-limiting toxicity was neutropenia, and the MTD was $70 \mathrm{mg} / \mathrm{m}^{2}$, whereas the MTD of free DOX was $50 \mathrm{mg} / \mathrm{m}^{2}$ [46]. Moreover, recent results from a Phase II study in patients with advanced adenocarcinoma of the esophagus and gastro-esophageal junction, demonstrated that SP1049C has a notable single-agent activity. The objective response was $47 \%$ for the evaluate patients with the micellar formulation, whereas it was $43 \%$ in the 


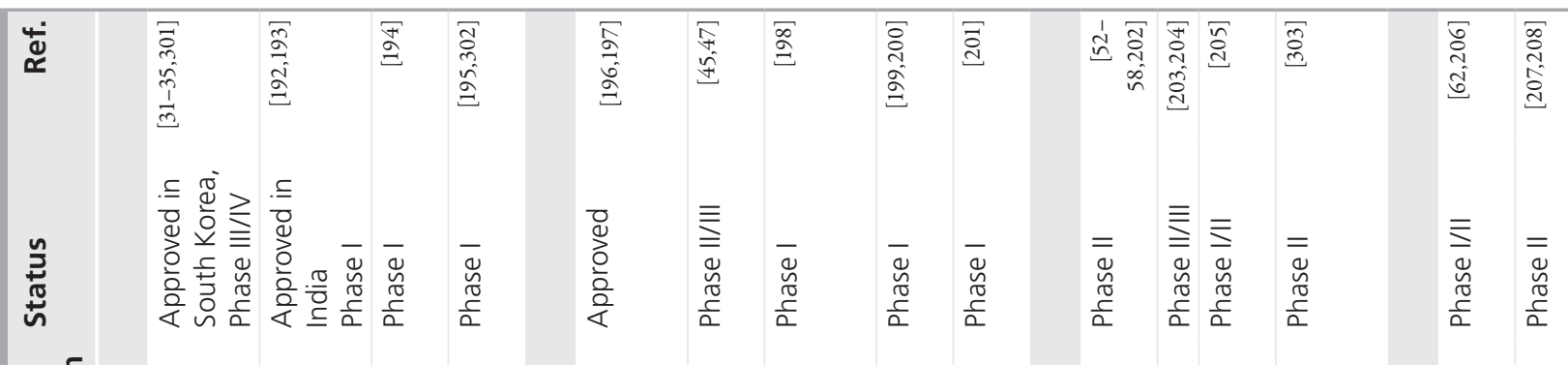

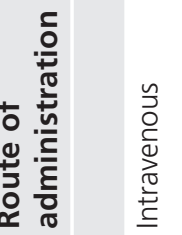

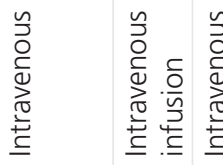

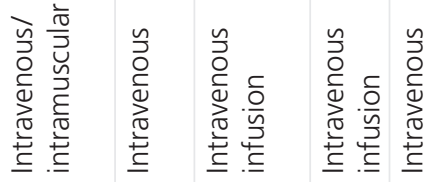

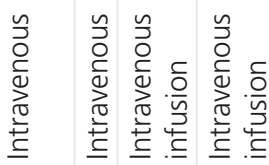

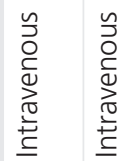

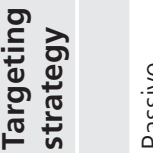

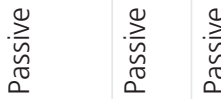

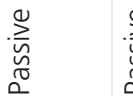

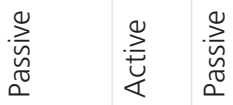

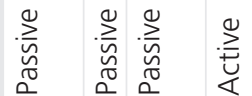

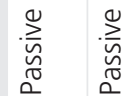

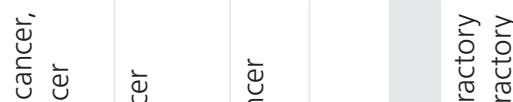

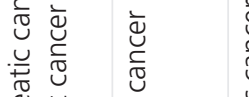

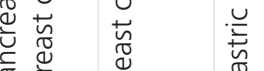

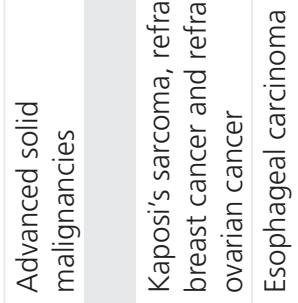

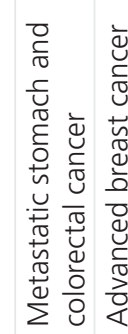

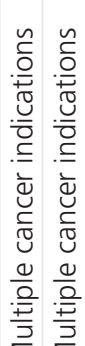

응

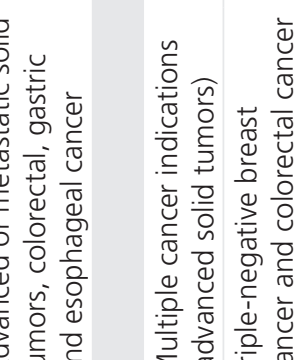

焉变

응 要旅

蚉

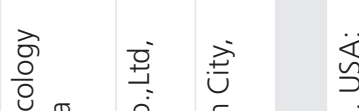

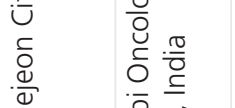

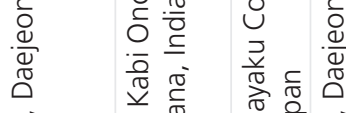

टे

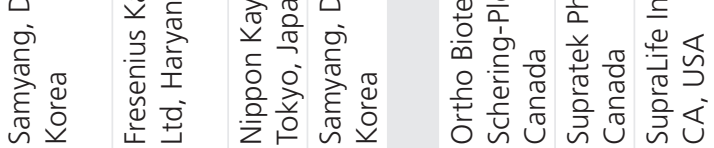

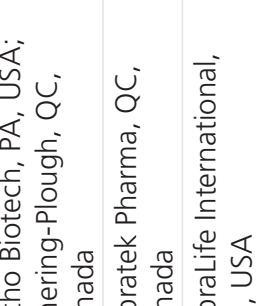

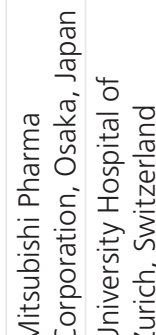

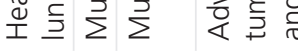

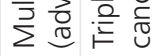

仓े

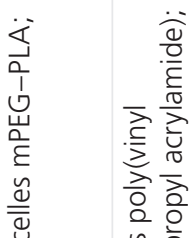

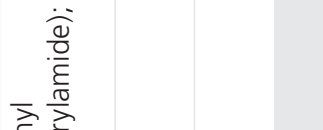

巡

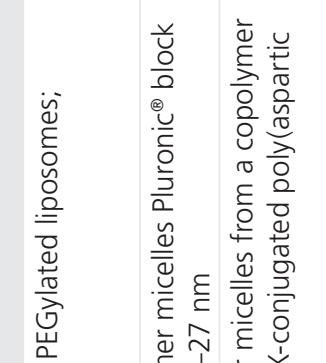

है 훙

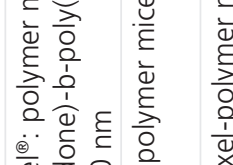

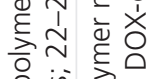

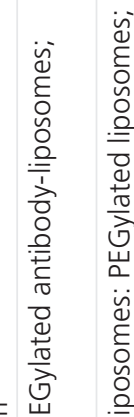

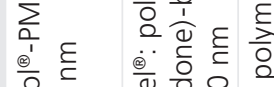

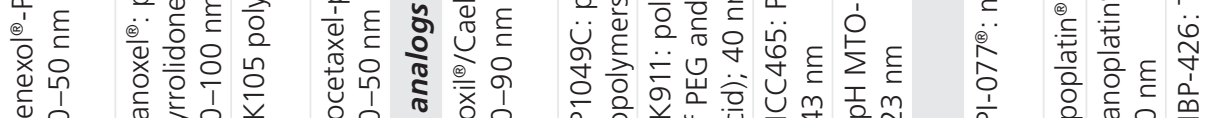

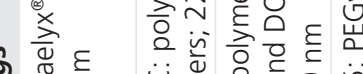

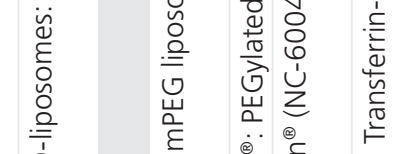

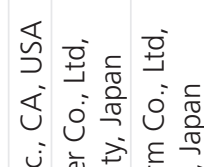

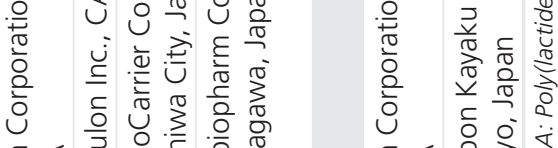

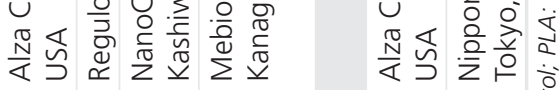

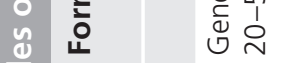

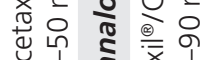

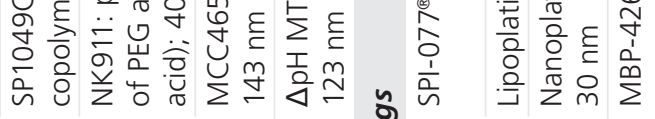

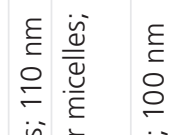

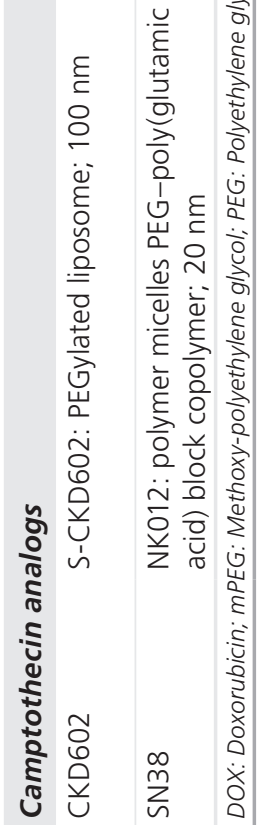

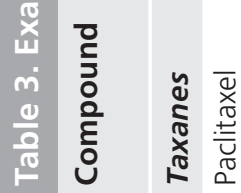
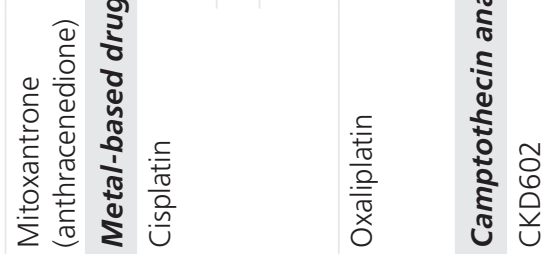
intent-to-treat population. The overall median survival and the progression-free survival were 10.0 and 6.6 months, respectively [47], while median survival of free DOX was not available. Nevertheless, with conventional therapy, which combines 5-fluorouracil with cisplatin, the median survival was 7 months, with epirubicin, cisplatin and 5-fluorouracil (ECF), the median survival was 8.9 months [48], and with 5-fluorouracil, doxorubicin and methotrexate, the median survival was 5.7 months [49].

\section{Metal-based drugs}

Cisplatin is one of the leading metal-based drugs used for the treatment of many malignancies. However, its expansion in clinical application is limited, owing to significant side effects, such as acute nephrotoxicity and chronic neurotoxicity [50]. Therefore, extensive efforts have been devoted to the specific delivery of cisplatin to tumor tissues. SPI-077 is a formulation of cisplatin, which is encapsulated in $\mathrm{mPEG}$ liposomes for the purpose of specific drug delivery and decreased cisplatin-related toxicity. Preclinical studies in mice demonstrated that SPI-077 exhibited increased efficacy against Lewis carcinomas and C26 colon carcinomas in $\mathrm{BALB} / \mathrm{c}$ mice, and was well tolerated with high cumulative doses [51]. Unfortunately, results from different Phase I and II studies of SPI-077 demonstrated the lack of efficacy of this formulation, since no response rates, or only modest response rates, were observed in patients with non-small-cell lung cancer or advanced head and neck cancer [52-58].

\section{Camptothecin analogs}

A camptothecin analog, 7-[2-( $N$-isopropylamino)ethyl]-(20S)-camptothecin, or CKD602 , was synthesized, and proven to be more potent than topotecan in 14 out of 26 human cancer cell lines tested [59]. CKD-602-loaded stealth liposomes (S-CKD-602) demonstrated prolonged circulation time in the plasma, resulting in threefold longer drug exposure in tumors, and improved antitumor efficacy compared with free drugs in nude mice bearing human tumor xenografts $[60,61]$. Recently, this stealth liposomal formulation of CKD-602 has entered a Phase I study in patients with advanced malignancies [62]. It was well tolerated, with a MTD of $2.1 \mathrm{mg} / \mathrm{m}^{2}$. The overall incidence of grade 3 or 4 toxicity was comparable to other camptothecins. Therefore, the Phase II studies of S-CKD-602 at a dose of $2.1 \mathrm{mg} / \mathrm{m}^{2}$, administered intravenously once every 3 weeks, have been planned [62].

\section{From passive to active targeting Drawbacks of passive targeting}

Most stealth NPs are expected to accumulate in the tumor site owing to the passive targeting. This passive targeting is, hence, highly dependent on the degree of tumor vascularization and angiogenesis [63,64]. Unfortunately, certain 
be nontoxic, and readily excreted by the kidneys, it is a nonbiodegradable polymer. It cannot be excluded that, after cellular uptake, PEG affects cell functioning at the long-term follow-up after internalization in the macrophages [73-75], as well as in liver, spleen, kidney and lung cells, where a considerable fraction of NPs can be found [76-78]. For example, some polymers may elicit immune response or allergic reactions, which are more likely following subsequent injections, although they may be controlled by corticosteroids and antihistamines. There were previous reports on the so-called 'macromolecular syndrome' or, more lately, on the infusion-related reaction, which is observed at first usage, even with antibody drugs or liposomal drugs, and is not observed in the second administration [64].

On the other hand, Ishida et al. reported that PEGylated liposomes lost their long-circulating property when they were administered twice in the same animal, and accumulated extensively in the liver [79]. This is referred to as the 'accelerated blood clearance' (ABC), the mechanism of which is related to the abundant production of anti-PEG IgM from the spleen in response to the first injection of PEGylated liposomes [80]. The IgM can selectively bind to the PEG chains on a second injection, administered several days later, and subsequently activates the complement system and enhances uptake of the second PEGylated liposome injection by the Kupffer cells $[81,82]$. Consequently, this ABC phenomenon may decrease the therapeutic effect of the loaded drug, and potentiate the adverse effects or even induce the morbidity [83,84]. This was also reported with other PEGylated nanocarriers, for example PEG-PLA NPs [85,86] and polymer micelles [87]. Therefore, further evidence is required to elucidate whether the $A B C$ mechanism is induced by all kinds of PEGylated NPs, and if it can occur in humans. Recently, it was observed that the $\mathrm{ABC}$ phenomenon could be prevented by changing the properties of the PEG lipid derivatives or by replacing the coating by other polymers (i.e., poly[amino acid]) [88]. Judge et al. [89] and Semple et al. [83] demonstrated the lack of this phenomenon by using PEG-conjugated ceramides (PEG-Cer), with a small C14 lipid anchor in modified liposomes. $\mathrm{Xu}$ et al. demonstrated that the use of other cleavable PEG-lipid derivatives could also prevent $A B C$ [90]. Indeed, repeated injection of conventional distearoylphosphatidylethanolamine (DSPE) PEG liposomes resulted in the enhanced elimination of liposomes, accompanied by increased accumulation in the liver. By contrast, the pharmacokinetic and biodistribution profiles after two injections of cholesteryl hemisuccinate (CHEMS) PEG liposomes were comparable to a single injection.

Finally, modifying the physicochemical properties of the NP surface, in order to render them as stealth NPs, in parallel can bring important drawbacks. For example, increasing the concentration of PEG is known to influence the surface polymer conformation and reduce the zeta potential of the nanocarriers in an interesting manner, but also increases their average diameter $[6,91]$, which can negatively influence the biodistribution of NPs [16]. More specifically, it can also limit cellular uptake by the endocytotic route [92]. As mentioned, a high density of PEG on the NP surface is necessary to improve in vivo blood circulation of the NPs, but the abundant presence of PEG may hinder the binding and uptake of nanocarriers by cancer cells by preventing nanocarrier/tumor cell contact [93]. Indeed, although PEGylated NPs frequently show superior in vivo antitumor activity, they are generally less cytotoxic in vitro than conventional NPs [94,95], owing to lack of interactions. Moreover, since most cytotoxic anticancer agents act intracellularly, the release of entrapped drugs from NPs must occur inside the tumor cells. Rapid leakage of the drug payload in the blood circulation may lead to a decrease in drug efficacy and potentiate an undesirable effect. Once they have arrived at the target tumor site, nanocarriers can release their content in close proximity to the target cells (i.e., in the case of passive targeting), attach to the membrane of the cell via nonspecific receptors and act as an extracellular sustained-release drug depot, or internalize into the cell before the drug is released owing to specific receptor-mediated internalization (FIgUre 3). When biopharmaceutical agents are not membrane permeable, such as proteins, peptides or nucleic acids, the extracellular release of the drug is not expected, and it is required that carriers are internalized to the target tumor cell in order to deliver the encapsulated drug to the appropriate location inside the cell. Therefore, the enhanced intracellular delivery by using PEGylated NPs without loss of drug activity (i.e., the improved bioavailability of drug), is a key step in drug delivery, which still remains a scientific challenge. As a consequence, in order to increase tumor localization, as well as tumor cell internalization, third-generation nanocarriers based on specific targeting have been developed. 


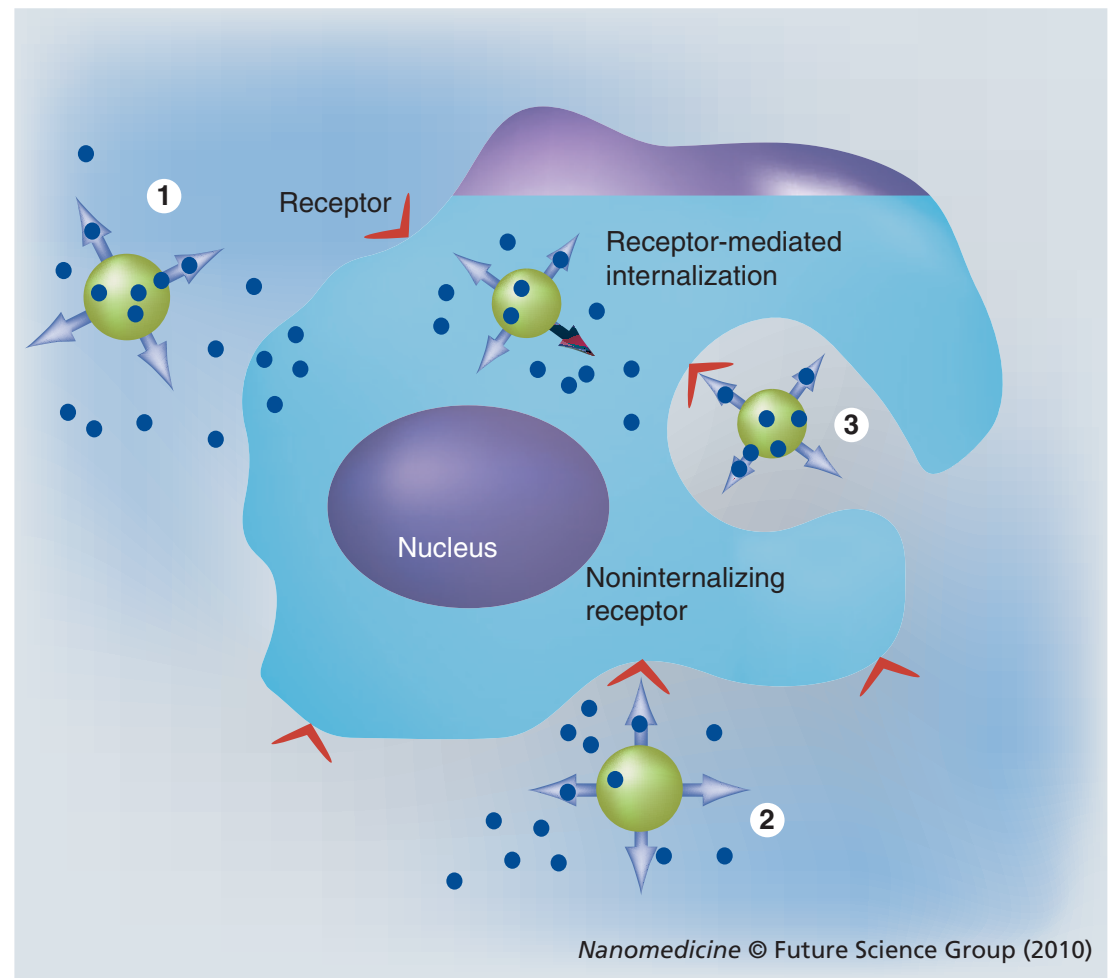

Figure 3. Mechanism of the drug release when reaching the tumor site (1-3).

Active ligand-conjugated stealth NPs Active targeting involves the use of peripherally conjugated targeting moiety (or ligand) for enhanced selective cellular binding due to specific interactions with receptors overexpressed on tumor cells. In some cases, it can be followed by the internalization of NPs through receptormediated endocytosis [96]. The targeting moieties are generally attached onto the surface of the colloidal particles, preferably at the end of the PEG molecules, since the targeted colloidal particles will be much more efficient if they are also sterically stabilized and, of course, considered stealth NPs [97]. Various targeting moieties have been employed for drug delivery systems, for example antibody fragments, peptides, sequences identified by phage display, small molecules or aptamers (Figure 4) $[98,99]$. Detailed descriptions of some active targeted NPs are depicted to illustrate the description of the ligands below.

\section{Antibodies}

Monoclonal antibodies (mAbs) or whole mAb fragments, including Fab' and single-chain Fv (scFv) fragments, have been widely used as ligands to target receptor-expressing cancer cells [100]. For example, an in vitro study by Kocbek et al. demonstrated that poly(lacticco-glycolic acid) (PLGA) NPs conjugated with $\mathrm{mAbs}$ were localized directly into MCF$10 \mathrm{~A}$ neoT cells, whereas noncoated NPs were distributed randomly [101]. Elsewhere, mAb 2C5-modified PEGylated liposomes, demonstrated three- to eight-fold increase in binding and internalization by various cancer cell lines of diverse origins, higher cytotoxicity towards various cancer cells and a significant therapeutic benefit over control (liposomes modified with a nonspecific $\operatorname{IgG})[102,103]$. Nevertheless, antibody fragments Fab' and $\mathrm{scFv}$, rather than intact $\mathrm{mAbs}$, were frequently used to minimize immunogenicity, and to circumvent clearance via Fc receptor-mediated mechanisms $[98,104]$. Kou et al. developed PLGA NPs coated with SM5-1 monoclonal antibody ( $\mathrm{scFv}$ ), which enhanced in vitro cytotoxicity against human hepatocellular carcinoma cell lines, and significantly inhibited tumor development and induced tumor regression [105]. Herceptin ${ }^{\circledR}$ is another therapeutic antibody targeting human EGF receptor-2 (HER2), which is overexpressed on breast cancer cell surfaces [100]. Studies using anti-HER 2 immunoliposomes, by conjugating anti-HER 2 antibody fragments to PEGylated liposomes, demonstrated that antiHER2 immunoliposomes achieved intracellular drug delivery via mAb-mediated endocytosis, whereas nontargeted liposomes were predominantly found in extracellular stroma or within macrophages [106]. DOX-loaded anti-HER2 immunoliposomes also showed significant antitumor effect compared with nontargeted liposomes [107]. However, although the authors demonstrated a high uptake of these immunoliposomes, the role of the active targeting is questionable. Indeed, in the same paper [108], the authors showed similar high levels of tumor tissue accumulation in HER2-overexpressing breast cancer xenografts (BT-474) between antiHER 2 immunoliposomes and nontargeted liposomes. Thus, in this case, targeted nanocarriers did not augment the tumor accumulation, as compared with nontargeted ones. The first explanation on the lack of accumulation is the type of model used in this paper. The study was performed with tumor cells, and not with tumor endothelial cells, which are the target. Another explanation is the high density of ligands on the NP surface. Indeed, the presence at a high density of active ligands can prevent the longcirculating properties of PEG, and lead to an accelerated elimination of NPs from the blood circulation [108]. Moreover, in order to use antibodies as a targeting moiety, different factors should be taken into consideration [96,109-112]: 
- The method of conjugation to incorporate antibodies to nanocarriers (i.e., conjugation could modify the activity of the antibody and its receptor affinity);

- The consequence of circulating free antibody;

- The immunogenicity of these entities, since most of them are derived from animals and 


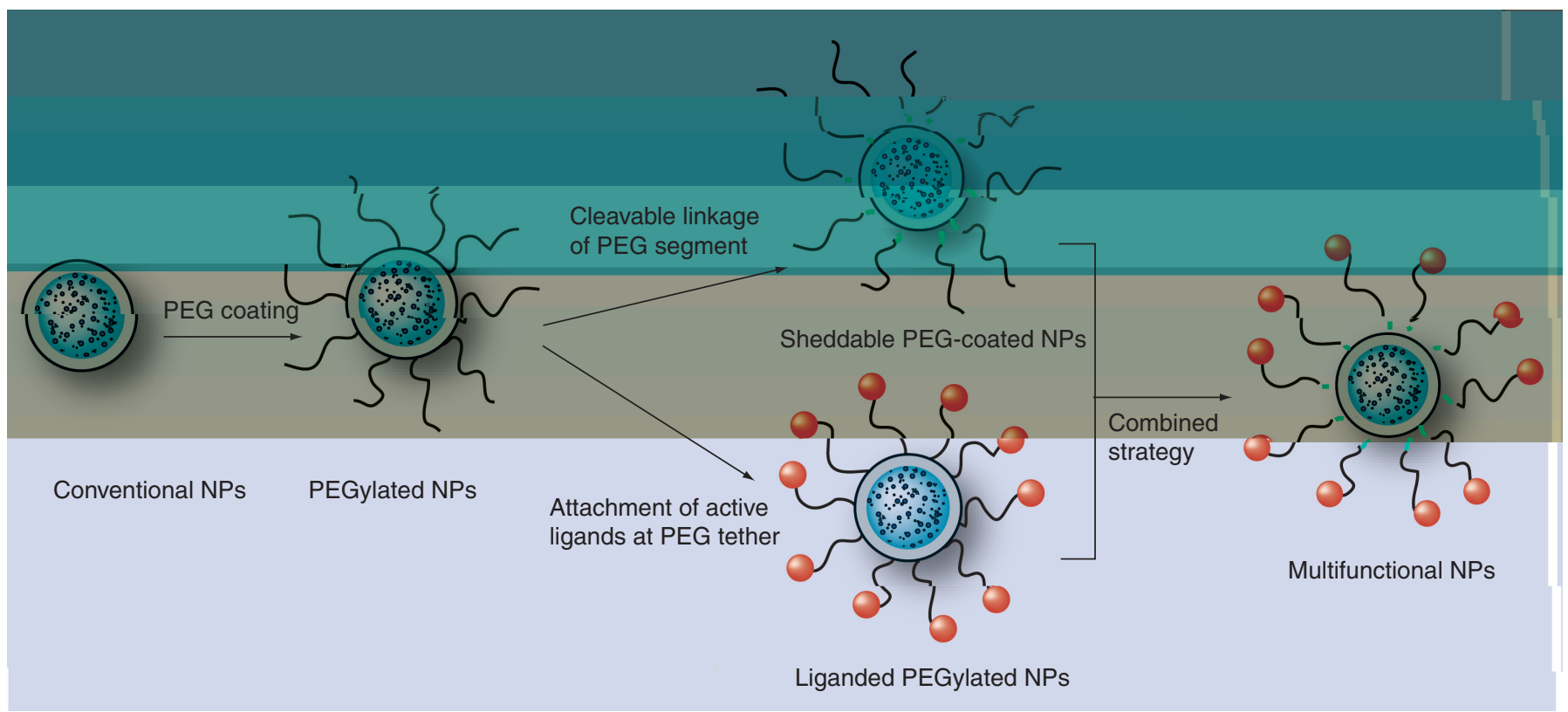

Figure 5. Different strategies for surface modifications from the conventional nanoparticles.

NP: Nanoparticle; PEG: Poly(ethylene glycol).

in many cancer cells that require folic acid for their rapid proliferation [124]. Folate-targeted liposomes have been shown to be effective carriers for intracellular delivery of nucleic acids and anticancer drugs to in vitro tumor cells [124]. Similarly, cell surface membrane lectins are also overexpressed at the surface of numerous cancer cells and able to specifically internalize sugar molecules via receptor-mediated endocytosis mechanisms, such as the mannose or fructose receptor of macrophages, and the asialoglycoprotein receptors of hepatocytes $[125,126]$.

In summary, it is noteworthy that active targeting using stealth NPs functionalized with ligands that have high-affinity levels and high specificity promises to be a powerful approach, leading to effective drug delivery into tumor cells for the treatment of cancer.

\section{Conclusion \& future perspective}

After intravenous administration, pharmacological activity of anticancer drugs is limited by various physiological barriers. The first barrier met by nanocarriers is their rapid elimination from the blood circulation, resulting from a nonspecific uptake by the MPS. Then, prior to reaching tumor cells, the second barrier is their extravasation out of the blood vessel. Finally, they need to bind and release the entrapped drug, generally inside the tumor cells.

To overcome the rapid elimination from systemic circulation, stealth NPs were developed, and already show promising results (e.g., commercial formulations and new clinical trials in process). When stealth, both targeted and nontargeted NPs are generally able to arrive at the tumor vicinity via the EPR effect. However, to date, in the majority of studies, the use of active targeted nanocarriers has not provided evidence of increased tumor accumulation after intravenous injection (TABLE 2) $[106,127]$, in spite of the presence of a specific ligand, except in the case of targeting specific cell types within the vasculature [128] (e.g., in order to reach the brain) [112]. However, there is an undeniable increase of therapeutic effect when the drug is loaded in active targeted NPs, owing to the enhancement of tumor cell internalization due to ligand-receptor interactions [106,129]. These active targeted NPs actually represent a very interesting therapeutic modality for the management of localized tumor when intratumoral injection is possible [118].

However, administration by intravenous route, despite a few encouraging results, still causes important problems. First, conjugation of active ligands may lead to an accelerated elimination of NPs by preventing their stealth properties, which, as described in this article, constitute the indispensable prerequisite. Thus, to add an active targeting agent, different parameters have to be considered (i.e., choice of ligands [130], method of coupling, concentration of ligands and control of ligand activity after coupling), as well as their influence on stealth properties. With passive targeted NPs, however, cell internalization could be prevented by a PEG layer, whereas active targeted counterparts can allow an increase in cellular uptake, which is an interesting advantage. 
Accordingly, active targeting increases drug efficacy, and decreases systemic toxicity owing to drug release in normal cells. However, arrival at the drug's target site is not guaranteed, and drug efficacy is greatly dependent on intracellular trafficking and subsequent transport.

Actually, in spite of the different advantages expected with active targeting, currently no active targeted NPs are on the market, and only a few formulations are subjected to clinical experiments (Table 3). Thus, many papers in the literature describe the procedure and the in vitro characterization of formulation; nevertheless, few articles on activity after in vivo study have been published. Is it linked to the complexity of the formulation processes of these active targeted NPs, the expensive price of the ligands and effective scaling-up production, the difficulty to formulate these systems in large quantities for in vivo studies, or quite simply, to the lack of activity? Consequently, since passive targeted NPs are easier to produce, and owing to the low benefit supplied with active targeting in comparison with passive targeting, passive targeting NPs have been promoted [131] and, nowadays, constitute an interesting and promising field in nanotechnology development.

As a consequence, attempts to improve the effectiveness and safety of chemotherapy have brought about several tumor-targeted drug delivery strategies. From the benefits of PEG coating, the engineering of drug delivery nanoscale systems is moving in the direction of 'smart' devices, which are specially homed to, and responsive in, their target environment only $[132,133]$. For example, stealth NPs can possess a PEG hydrophilic surface, which is able to vanish upon arrival at the site of interest by the cleavage of a sensitive linkage via chemical stimuli, such as the presence of low $\mathrm{pH}$ or reducing agents, or enzymatic stimuli, such as proteases [134,135]. Nanocarriers could then be transformed to a more cell-interactive form, by restoring the possible interaction of the targeting moieties with the cell membrane receptors, once the tumor site is attained, and improving drug bioavailability [136]. For instance, Romberg et al. prepared long-circulating liposomes with an enzymatically degradable coating polymer that triggers cellular uptake of liposomes and/or release of the entrapped biologically active agent [88]. Such promising strategies offer not only a great increase in the intrinsic pharmacologic effect of drug-loaded in NPs for therapeutic success, but also prevention of interactions at nonspecific sites. In the near future, more safe and effective nanotechnology anticancer products for cancer therapy are expected, especially nanocarriers with multivalent properties (e.g., stealth, specific targeting, internalization and drug controlled release) (Figure $3 \& 5$ ).

\section{Executive summary}

\section{Background}

- Stealth nanoparticles still represent a promising generation of nanocarriers for cancer therapy.

Passive targeting

- Surface PEGylation has been successfully applied to various types of nanoparticles, such as liposomes, polymer nanoparticles, lipid nanoparticles and micelles. Polyethylene glycol coating confers to nanoparticles the stealth properties that limit nanoparticle elimination by the mononuclear phagocyte system in the bloodstream and allow tumor accumulation by the enhanced permeability and retention effect.

- Polyethylene glycol nanoparticles loaded with various anticancer drugs (e.g., taxanes, anthracyclines, metal-based drugs and camptothecin analogs) have shown promising results. These nanocarriers have entered clinical trials in humans and some are approved by the US FDA

- Various parameters have to be taken into consideration, such as PEGylation process versus physicochemical characteristics of nanoparticles, tumor vasculature versus passive accumulation of nanoparticles, and safety versus efficacy of anticancer-loaded nanoparticles.

\section{Active targeting}

- Active targeted nanoparticles can be prepared with active ligands that confer selective cellular binding. Ligands can be antibodies, nucleic acid aptamers, peptides and small molecules, such as folic acid and sugar molecules.

- There is an undeniable increase of therapeutic effect when drug is loaded in active targeted nanoparticles thanks to the enhancement of tumor cell internalization due to the ligand/receptor interactions.

- In order to keep stealth properties with active targeted nanoparticles, various parameters have to be taken into consideration (e.g., choice of ligand, method of coupling and density of ligands). The control of ligand activity after coupling must be checked.

\section{Conclusion}

- Stealth nanocarriers can be designed to optimize chemotherapy after intravenous administration thanks to passive accumulation into tumor.

- Active strategy promises to be a powerful approach leading to effective drug delivery into tumor cells for the treatment of cancer, provided that stealth properties are kept.

- Beside the stealth and active properties, it would be interesting to design nanocarriers of new generation, being able to control drug release in the specific target. Thus, the multifunctional 'smart' devices represent the future nanomedicines. 


\section{Acknowledgements}

The authors would like to thank Pr. Mai Phuong Mai for her kind support.

Financial \& competing interests disclosure This work is supported by grants from the Evarist Galoir fellowship of the Embassy of France in Viet Nam and from

'La Ligue Nationale Contre le Cancer'. The authors have no other relevant affiliations or financial involvement with

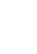


34 Park SR, Oh DY, Kim DW et al:: A multicenter, late Phase II clinical trial of Genexol (paclitaxel) and cisplatin for patients with advanced gastric cancer. Oncol. Rep. 12(5), 1059-1064 (2004).

35 Wang X, Wang Y, Chen ZG, Shin DM: Advances of cancer therapy by nanotechnology. Cancer Res. Treat. 41(1), 1-11 (2009).

36 Yeh ET, Tong AT, Lenihan DJ et al: Cardiovascular complications of cancer therapy: diagnosis, pathogenesis, and management. Circulation 109(25), 3122-3131 (2004).

37 Thigpen JT, Aghajanian CA, Alberts DS et al: Role of PEGylated liposomal doxorubicin in ovarian cancer. Gynecol. Oncol. 96(1), 10-18 (2005).

38 Ranson MR, Cheeseman S, White S, Margison J: Caelyx (stealth liposomal doxorubicin) in the treatment of advanced breast cancer. Crit. Rev. Oncol. Hematol. 37(2), 115-120 (2001).

39 Gabizon A, Shmeeda H, Barenholz Y: Pharmacokinetics of PEGylated liposomal doxorubicin: review of animal and human studies. Clin. Pharmacokinet. 42(5), 419-436 (2003).

- Summarizes studies on the pharmacokinetic profiles of doxorubicin (DOX)-loaded PEG liposomes.

40 Solomon R, Gabizon AA: Clinical pharmacology of liposomal anthracyclines: focus on PEGylated liposomal doxorubicin. Clin. Lymphoma Myeloma 8(1), 21-32 (2008)

41 Gabizon AA: PEGylated liposomal doxorubicin: metamorphosis of an old drug into a new form of chemotherapy. Cancer Invest. 19(4), 424-436 (2001).

42 Verma S, Dent S, Chow BJ, Rayson D, Safra T: Metastatic breast cancer: the role of PEGylated liposomal doxorubicin after conventional anthracyclines. Cancer Treat. Rev. 34(5), 391-406 (2008).

43 Venne A, Li S, Mandeville R, Kabanov A, Alakhov V: Hypersensitizing effect of Pluronic L61 on cytotoxic activity, transport, and subcellular distribution of doxorubicin in multiple drug-resistant cells. Cancer Res. 56(16), 3626-3629 (1996).

44 Alakhov V, Klinski E, Li S et al.: Block copolymer-based formulation of doxorubicin. From cell screen to clinical trials. Colloids Surf. B. Biointerfaces 16(1-4), 113-134 (1999).

45 Danson S, Ferry D, Alakhov V et al:: Phase I dose escalation and pharmacokinetic study of pluronic polymer-bound doxorubicin (SP1049C) in patients with advanced cancer. Br. J. Cancer 90(11), 2085-2091 (2004).
46 Duska LR, Penson R, Supko JG et al:: A Phase I study of continuous infusion doxorubicin and paclitaxel chemotherapy with granulocyte colony-stimulating factor for relapsed epithelial ovarian cancer. Clin. Cancer Res. 
70 Heldin $\mathrm{CH}$, Rubin K, Pietras K, Östman A: High interstitial fluid pressure - an obstacle in cancer therapy. Nat. Rev. Cancer 4(10), 806-813 (2004)

71 Vert M: Degradable and bioresorbable polymers in surgery and in pharmacology: beliefs and facts. J. Mater. Sci. Mater. Med. 20(2), 437-446 (2009).

72 Passirani C, Barratt G, Devissaguet JP, Labarre D: Interactions of nanoparticles bearing heparin or dextran covalently bound to poly(methyl methacrylate) with the complement system. Life Sci. 62 (8), 775-785 (1998).

73 Wang ZY, Stern IJ: Disposition in rats of a polyoxypropylene-polyoxyethylene copolymer used in plasma fractionation. Drug Metab. Dispos. 3(6), 536-542 (1975).

74 Kwon GS, Yokoyama M, Okano T, Sakurai Y, Kataoka K: Biodistribution of micelleforming polymer-drug conjugates. Pharm. Res. 10(7), 970-974 (1993).

75 Hunter AC, Moghimi SM: Therapeutic synthetic polymers: a game of Russian roulette? Drug Discov. Today 7(19), 998-1001 (2002).

76 Li S-D, Huang L: Nanoparticles evading the reticuloendothelial system: role of the supported bilayer. Biochim. Biophys. Acta 1788(10), 2259-2266 (2009).

77 Sheng Y, Liu C, Yuan Y et al.: Longcirculating polymeric nanoparticles bearing a combinatorial coating of PEG and watersoluble chitosan. Biomaterials 30(12), 2340-2348 (2009).

78 Shan X, Liu C, Yuan Y et al.: In vitro macrophage uptake and in vivo biodistribution of long-circulation nanoparticles with poly(ethylene-glycol)modified PLA (BAB type) triblock copolymer. Colloids Surf. B. Biointerfaces 72(2), 303-311 (2009).

79 Ishida T, Maeda R, Ichihara M, Irimura K, Kiwada H: Accelerated clearance of PEGylated liposomes in rats after repeated injections. J. Control. Release 88(1), 35-42 (2003).

80 Ishida T, Kiwada H: Accelerated blood clearance $(\mathrm{ABC})$ phenomenon upon repeated injection of PEGylated liposomes. Int. J. Pharm. 354(1-2), 56-62 (2008).

81 Ishida T, Ichihara M, Wang X, Kiwada H: Spleen plays an important role in the induction of accelerated blood clearance of PEGylated liposomes. J. Control. Release 115(3), 243-250 (2006).

82 Wang X, Ishida T, Kiwada H: Anti-PEG IgM elicited by injection of liposomes is involved in the enhanced blood clearance of a subsequent dose of PEGylated liposomes. J. Control. Release 119(2), 236-244 (2007).
83 Semple SC, Harasym TO, Clow KA, Ansell SM, Klimuk SK, Hope MJ: Immunogenicity and rapid blood clearance of liposomes containing polyethylene glycol-lipid conjugates and nucleic acid. J. Pharmacol. Exp. Ther. 312(3), 1020-1026 (2005).

84 Laverman P, Carstens MG, Boerman OC et al:: Factors affecting the accelerated blood clearance of polyethylene glycol-liposomes upon repeated injection. J. Pharmacol. Exp. Ther. 298(2), 607-612 (2001).

85 Ishihara $\mathrm{T}$, Takeda $\mathrm{M}$, Sakamoto $\mathrm{H}$ et al. Accelerated blood clearance phenomenon upon repeated injection of PEG-modified PLA-nanoparticles. Pharm. Res. 26(10), 2270-2279 (2009).

86 Lu W, Wan J, She Z, Jiang X: Brain delivery property and accelerated blood clearance of cationic albumin conjugated PEGylated nanoparticle. J. Control. Release 118(1), 38-53 (2007)

87 Koide H, Asai T, Hatanaka K et al.: Particle size-dependent triggering of accelerated blood clearance phenomenon. Int. J. Pharm. 362(1-2), 197-200 (2008).

88 Romberg B, Metselaar JM, deVringer T et al: Enzymatic degradation of liposome-grafted poly(hydroxyethyl L-glutamine). Bioconjug. Chem. 16(4), 767-774 (2005).

89 Judge A, McClintock K, Phelps JR, Maclachlan I: Hypersensitivity and loss of disease site targeting caused by antibody responses to PEGylated liposomes. Mol. Ther. 13(2), 328-337 (2006).

90 Xu H, Wang KQ, Deng YH, Chen da W: Effects of cleavable PEG-cholesterol derivatives on the accelerated blood clearance of PEGylated liposomes. Biomaterials 31(17), 4757-4763 (2010).

91 Zara GP, Cavalli R, Bargoni A, Fundaro A, Vighetto D, Gasco MR: Intravenous administration to rabbits of non-stealth and stealth doxorubicin-loaded solid lipid nanoparticles at increasing concentrations of stealth agent: pharmacokinetics and distribution of doxorubicin in brain and other tissues. J. Drug Target 10(4), 327-335 (2002).

92 Duncan R: Polymer conjugates as anticancer nanomedicines. Nat. Rev. Cancer 6(9), 688-701 (2006)

93 Hong RL, Huang CJ, Tseng YL et al.: Direct comparison of liposomal doxorubicin with or without polyethylene glycol coating in C-26 tumor-bearing mice: is surface coating with polyethylene glycol beneficial? Clin. Cancer Res. 5(11), 3645-3652 (1999).

94 Immordino ML, Brusa P, Arpicco S, Stella B, Dosio F, Cattel L: Preparation, characterization, cytotoxicity and pharmacokinetics of liposomes containing docetaxel. J. Control. Release 91(3), 417-429 (2003).

95 Yang T, Cui FD, Choi MK et al.: Enhanced solubility and stability of PEGylated liposomal paclitaxel: in vitro and in vivo evaluation. Int. J. Pharm. 338(1-2), 317-326 (2007).

96 Byrne JD, Betancourt T, Brannon-Peppas L: Active targeting schemes for nanoparticle systems in cancer therapeutics. Adv. Drug Deliv. Rev. 60 (15), 1615-1626 (2008).

97 Maruyama K: PEG-immunoliposome. Biosci. Rep. 22(2), 251-266 (2002).

98 Marcucci F, Lefoulon F: Active targeting with particulate drug carriers in tumor therapy: fundamentals and recent progress. Drug Discov. Today 9(5), 219-228 (2004).

99 Allen TM: Ligand-targeted therapeutics in anticancer therapy. Nat. Rev. Cancer 2(10), 750-763 (2002).

100 Weiner LM, Adams GP: New approaches to antibody therapy. Oncogene 19(53), 6144-6151 (2000).

101 Kocbek P, Obermajer N, Cegnar M, Kos J, Kristl J: Targeting cancer cells using PLGA nanoparticles surface modified with monoclonal antibody. J. Control. Release 120 (1-2), 18-26 (2007).

102 Elbayoumi TA, Torchilin VP: Enhanced cytotoxicity of monoclonal anticancer antibody 2C5-modified doxorubicin-loaded PEGylated liposomes against various tumor cell lines. Eur. J. Pharm. Sci. 32(3), 159-168 (2007).

103 Gupta B, Torchilin VP: Monoclonal antibody 2C5-modified doxorubicin-loaded liposomes with significantly enhanced therapeutic activity against intracranial human brain U-87 MG tumor xenografts in nude mice. Cancer Immunol. Immunother. 56(8), 1215-1223 (2007).

104 Presta LG: Engineering of therapeutic antibodies to minimize immunogenicity and optimize function. Adv. Drug Deliv. Rev. 58(5-6), 640-656 (2006).

105 Kou G, Gao J, Wang H et al:: Preparation and characterization of paclitaxel-loaded PLGA nanoparticles coated with cationic SM5-1 single-chain antibody. J. Biochem. Mol. Biol. 40 (5), 731-739 (2007).

106 Kirpotin DB, Shao Y: Antibody targeting of long-circulating lipidic nanoparticles does not increase tumor localization but does increase internalization in animal models. Cancer Res. 66(13), 6732-6740 (2006).

"- Intersting report showing the similar high level of tumor site accumulation of targeted nanoparticles (NPs) and nontargeted counterparts. 
107 Park JW, Hong K, Kirpotin DB et al.: Anti-HER2 immunoliposomes: enhanced efficacy attributable to targeted delivery. Clin. Cancer Res. 8(4), 1172-1181 (2002).

108 Hansen CB, Kao GY, Moase EH, Zalipsky S, Allen TM: Attachment of antibodies to sterically stabilized liposomes: evaluation, comparison and optimization of coupling procedures. Biochim. Biophys. Acta 1239(2), 133-144 (1995).

109 Popielarski SR, Pun SH, Davis ME: A nanoparticle-based model delivery system to guide the rational design of gene delivery to the liver. 1. Synthesis and characterization. Bioconjug. Chem. 16(5), 1063-1070 (2005).

110 Akerman ME, Chan WC, Laakkonen P, Bhatia SN, Ruoslahti E: Nanocrystal targeting in vivo. Proc. Natl Acad. Sci. USA 99(20), 12617-12621 (2002).

111 Gref R, Couvreur P, Barratt G, Mysiakine E: Surface-engineered nanoparticles for multiple ligand coupling. Biomaterials 24(24), 4529-4537 (2003).

112 Beduneau A, Saulnier P, Benoit JP: Active targeting of brain tumors using nanocarriers. Biomaterials 28(33), 4947-4967 (2007).

113 Matzku S, Krempel H, Weckenmann HP, Schirrmacher V, Sinn H, Stricker H: Tumor targeting with antibody-coupled liposomes: failure to achieve accumulation in xenografts and spontaneous liver metastases. Cancer Immunol. Immunother. 31(5), 285-291 (1990).

114 Arruebo M, Valladares M, GonzálezFernández A: Antibody-conjugated nanoparticles for biomedical applications. J. Nanomaterials 2009, 439389 (2009).

115 Nimjee SM, Rusconi CP, Sullenger BA: Aptamers: an emerging class of therapeutics. Annu. Rev. Med. 56, 555-583 (2005).

116 Blank M, Blind M: Aptamers as tools for target validation. Curr. Opin. Chem. Biol. 9(4), 336-342 (2005).

117 Farokhzad OC, Jon S, Khademhosseini A, Tran TN, Lavan DA, Langer R: Nanoparticle-aptamer bioconjugates: a new approach for targeting prostate cancer cells. Cancer Res. 64(21), 7668-7672 (2004).

118 Farokhzad OC, Cheng J, Teply BA et al.: Targeted nanoparticle-aptamer bioconjugates for cancer chemotherapy in vivo. Proc. Natl Acad. Sci. USA 103(16), 6315-6320 (2006).

119 Cheng J, Teply BA, Sherifi I et al.: Formulation of functionalized PLGA-PEG nanoparticles for in vivo targeted drug delivery. Biomaterials 28(5), 869-876 (2007).

120 Temming K, Schiffelers RM, Molema G, Kok RJ: RGD-based strategies for selective delivery of therapeutics and imaging agents to the tumor vasculature. Drug Resist. Updat. 8(6), 381-402 (2005).
121 Schiffelers RM, Koning GA, Ten Hagen TL et al:: Anti-tumor efficacy of tumor vasculature-targeted liposomal doxorubicin. J. Control. Release 91(1-2), 115-122 (2003).

122 Sugahara KN, Teesalu T, Karmali PP et al. Tissue-penetrating delivery of compounds and nanoparticles into tumors. Cancer Cell 16(6), 510-520 (2009).

123 Alexis F, Rhee JW, Richie JP, RadovicMoreno AF, Langer R, Farokhzad OC: New frontiers in nanotechnology for cancer treatment. Urol. Oncol. 26(1), 74-85 (2008).

124 Wang S, Low PS: Folate-mediated targeting of antineoplastic drugs, imaging agents, and nucleic acids to cancer cells. J. Control. Release 53(1-3), 39-48 (1998).

125 Barratt GM: Therapeutic applications of colloidal drug carriers. Pharm. Sci. Technol. Today 3(5), 163-171 (2000).

126 Morille M, Passirani C, Letrou-Bonneval E, Benoit JP, Pitard B: Galactosylated DNA lipid nanocapsules for efficient hepatocyte targeting. Int. J. Pharm. 379(2), 293-300 (2009).

127 Pirollo KF, Chang EH: Does a targeting ligand influence nanoparticle tumor localization or uptake? Trends Biotechnol. 26(10), 552-558 (2008).

128 Faraji AH, Wipf P: Nanoparticles in cellular drug delivery. Bioorg. Med. Chem. 17(8), 2950-2962 (2009).

129 Ruoslahti E, Bhatia SN, Sailor MJ: Targeting of drugs and nanoparticles to tumors. J. Cell Biol. 188(6), 759-768 (2010).

130 Maruyama K, Takahashi N, Tagawa T, Nagaike K, Iwatsuru M: Immunoliposomes bearing polyethyleneglycol-coupled Fab' fragment show prolonged circulation time and high extravasation into targeted solid tumors in vivo. FEBS Lett. 413(1), 177-180 (1997).

131 Eaton M: Nanomedicine: industry-wise research. Nat. Mater. 6(4), 251-253 (2007).

132 Torchilin V: Multifunctional and stimulisensitive pharmaceutical nanocarriers. Eur. J. Pharm. Biopharm. 71(3), 431-444 (2009).

133 Breunig M, Bauer S, Goepferich A: Polymers and nanoparticles: intelligent tools for intracellular targeting? Eur. J. Pharm. Biopharm. 68(1), 112-128 (2008).

134 Van Butsele K, Jérôme R, Jérôme C: Functional amphiphilic and biodegradable copolymers for intravenous vectorisation. Polymer 48(26), 7431-7443 (2007).

135 Van Butsele K, Sibret P, Fustin CA et al: Synthesis and $\mathrm{pH}$-dependent micellization of diblock copolymer mixtures. J. Colloid Interface Sci. 329(2), 235-243 (2009).
136 Gullotti E, Yeo Y: Extracellularly activated nanocarriers: a new paradigm of tumor targeted drug delivery. Mol. Pharm. 6(4), 1041-1051 (2009).

137 Vittaz M, Bazile D, Spenlehauer G et al.: Effect of PEO surface density on longcirculating PLA-PEO nanoparticles which are very low complement activators. Biomaterials 17(16), 1575-1581 (1996).

138 Dos Santos N, Allen C, Doppen AM et al:: Influence of poly(ethylene glycol) grafting density and polymer length on liposomes: relating plasma circulation lifetimes to protein binding. Biochim. Biophys. Acta 1768(6), 1367-1377 (2007).

- Discusses the influence of the proportion and molecular weight of PEG on the circulation longevity of PEG liposomes.

139 Yang T, Cui FD, Choi MK et al: : Enhanced solubility and stability of PEGylated liposomal paclitaxel: in vitro and in vivo evaluation. Int. J. Pharm. 338(1-2), 317-326 (2007).

140 Unezaki S, Maruyama K, Hosoda JI et al.: Direct measurement of the extravasation of polyethyleneglycol-coated liposomes into solid tumor tissue by in vivo fluorescence microscopy. Int. J. Pharm. 144(1), 11-17 (1996).

- Reference article underlying the mechanism of the extravasation of PEG liposomes into the tumor.

141 Unezaki S, Maruyama K, Ishida O, Suginaka A, Hosoda JI, Iwatsuru M: Enhanced tumor targeting and improved antitumor activity of doxorubicin by long-circulating liposomes containing amphipathic poly(ethylene glycol). Int. J. Pharm. 126(1-2), 41-48 (1995).

142 Hoarau D, Delmas P, David S, Roux E, Leroux JC: Novel long-circulating lipid nanocapsules. Pharm. Res. 21(10), 1783-1789 (2004).

143 Khalid MN, Simard P, Hoarau D, Dragomir A, Leroux JC: Long circulating poly(ethylene glycol)-decorated lipid nanocapsules deliver docetaxel to solid tumors. Pharm. Res. 23(4), 752-758 (2006).

144 Crosasso P, Ceruti M, Brusa P, Arpicco S, Dosio F, Cattel L: Preparation, characterization and properties of $\mathrm{Mile}$ 
146 Fundaro A, Cavalli R, Bargoni A, Vighetto D, Zara GP, Gasco MR: Non-stealth and stealth solid lipid nanoparticles (SLN) carrying doxorubicin: pharmacokinetics and tissue distribution after i.v. administration to rats. Pharmacol. Res. 42(4), 337-343 (2000).

147 Podio V, Zara GP, Carazzone M, Cavalli R, Gasco MR: Biodistribution of stealth and non-stealth solid lipid nanospheres after intravenous administration to rats. J. Pharm. Pharmacol. 52(9), 1057-1063 (2000).

148 Beduneau A, Saulnier P, Anton N et al.: PEGylated nanocapsules produced by an organic solvent-free method: evaluation of their stealth properties. Pharm. Res. 23(9), 2190-2199 (2006).

149 Gref R, Luck M, Quellec P et al:: 'Stealth' corona-core nanoparticles surface modified by polyethylene glycol (PEG): influences of the corona (PEG chain length and surface density) and of the core composition on phagocytic uptake and plasma protein adsorption. Colloids Surf. B. Biointerfaces 18(3-4), 301-313 (2000).

150 Bazile D, Prud'homme C, Bassoullet MT, Marlard M, Spenlehauer G, Veillard M: Stealth Me.PEG-PLA nanoparticles avoid uptake by the mononuclear phagocytes system. J. Pharm. Sci. 84(4), 493-498 (1995).

151 Verrecchia T, Spenlehauer G, Bazile DV, Murry-Brelier A, Archimbaud Y, Veillard M: Non-stealth (poly(lactic acid/albumin)) and stealth (poly(lactic acid-polyethylene glycol)) nanoparticles as injectable drug carriers. J. Control. Release 36(1-2), 49-61 (1995).

152 Shan X, Yuan Y, Liu C, Xu F, Sheng Y: Comparison of the PLA-mPEG and mPEGPLA-mPEG copolymers nanoparticles on the plasma protein adsorption and in vivo biodistribution. Soft Matter 5(15), 2875-2883 (2009).

153 Dong Y, Feng SS: In vitro and in vivo evaluation of methoxy polyethylene glycolpolylactide (mPEG-PLA) nanoparticles for small-molecule drug chemotherapy. Biomaterials 28(28), 4154-4160 (2007).

154 Yamamoto Y, Nagasaki Y, Kato Y, Sugiyama Y, Kataoka K: Long-circulating poly(ethylene glycol)-poly(D,L-lactide) block copolymer micelles with modulated surface charge. $J$. Control. Release 77(1-2), 27-38 (2001).

155 Mattheolabakis G, Taoufik E, Haralambous S, Roberts ML, Avgoustakis K: In vivo investigation of tolerance and antitumor activity of cisplatin-loaded PLGAmPEG nanoparticles. Eur. J. Pharm. Biopharm. 71(2), 190-195 (2009).

156 Park J, Fong PM, Lu J et al.: PEGylated PLGA nanoparticles for the improved delivery of doxorubicin. Nanomedicine 5(4), 410-418 (2009).
157 Avgoustakis K, Beletsi A, Panagi Z et al.: Effect of copolymer composition on the physicochemical characteristics, in vitro stability, and biodistribution of PLGA-mPEG nanoparticles. Int. J. Pharm. 259(1-2), 115-127 (2003).

158 Li Y, Pei Y, Zhang X et al.: PEGylated PLGA nanoparticles as protein carriers: synthesis, preparation and biodistribution in rats. J. Control. Release 71(2), 203-211 (2001).

159 Panagi Z, Beletsi A, Evangelatos G, Livaniou E, Ithakissios DS, Avgoustakis K: Effect of dose on the biodistribution and pharmacokinetics of PLGA and PLGAmPEG nanoparticles. Int. J. Pharm. 221(1-2), 143-152 (2001).

160 Danhier F, Lecouturier N, Vroman B et al.: Paclitaxel-loaded PEGylated PLGA-based nanoparticles: in vitro and in vivo evaluation. J. Control. Release 133(1), 11-17 (2009).

161 Senthilkumar M, Mishra P, Jain NK: Long circulating PEGylated poly(D,L-lactide-coglycolide) nanoparticulate delivery of docetaxel to solid tumors. J. Drug Target 16(5), 424-435 (2008).

162 Gryparis EC, Hatziapostolou M, Papadimitriou E, Avgoustakis K: Anticancer activity of cisplatin-loaded PLGA-mPEG nanoparticles on LNCaP prostate cancer cells. Eur. J. Pharm. Biopharm. 67(1), 1-8 (2007).

163 Peracchia MT, Fattal E, Desmaele D et al.: Stealth PEGylated polycyanoacrylate nanoparticles for intravenous administration and splenic targeting. J. Control. Release 60(1), 121-128 (1999).

164 Huang M, Wu W, Qian J, Wan DJ, Wei XL, Zhu JH: Body distribution and in situ evading of phagocytic uptake by macrophages of long-circulating poly (ethylene glycol) cyanoacrylate-co- $N$-hexadecyl cyanoacrylate nanoparticles. Acta Pharmacol. Sin. 26(12), 1512-1518 (2005).

165 Calvo P, Gouritin B, Chacun $\mathrm{H}$ et al. Long-circulating PEGylated polycyanoacrylate nanoparticles as new drug carrier for brain delivery. Pharm. Res. 18(8), 1157-1166 (2001).

166 Brigger I, Morizet J, Aubert G et al. Poly(ethylene glycol)-coated hexadecylcyanoacrylate nanospheres display a combined effect for brain tumor targeting. J. Pharmacol. Exp. Ther. 303(3), 928-936 (2002).

167 Kim HR, Gil S, Andrieux K et al.: Lowdensity lipoprotein receptor-mediated endocytosis of PEGylated nanoparticles in rat brain endothelial cells. Cell Mol. Life Sci. 64(3), 356-364 (2007)

168 Kim HR, Andrieux K, Gil S et al.: Translocation of poly(ethylene glycol-cohexadecyl)cyanoacrylate nanoparticles into rat brain endothelial cells: role of apolipoproteins in receptor-mediated endocytosis. Biomacromolecules 8(3), 793-799 (2007).

169 Zhang L, Hu Y, Jiang X, Yang C, Lu W, Yang YH: Camptothecin derivative-loaded poly(caprolactone-co-lactide)-b-PEG-bpoly(caprolactone-co-lactide) nanoparticles and their biodistribution in mice. J. Control. Release 96(1), 135-148 (2004).

170 Zhang L, Yang M, Wang Q et al.: 10-hydroxycamptothecin loaded nanoparticles: preparation and antitumor activity in mice. J. Control. Release 119(2), 153-162 (2007).

171 Gou M, Zheng X, Men K et al.: Poly(ecaprolactone)/poly(ethylene glycol)/ poly(epsilon-caprolactone) nanoparticles: preparation, characterization, and application in doxorubicin delivery. J. Phys. Chem. B 113(39), 12928-12933 (2009).

172 Nakada Y, Tudomi R, Sakurai K, Takahashi Y: Evaluation of long-circulating nanoparticles using biodegradable ABA triblock copolymers containing of poly $(\mathrm{L}-$ lactic acid) A-blocks attached to central poly(oxyethylene) B-blocks in vivo. Int. J. Pharm. 175(1), 109-117 (1998).

173 Matsumoto J, Nakada Y, Sakurai K, Nakamura T, Takahashi Y: Preparation of nanoparticles consisted of poly(-lactide)poly(ethylene glycol)-poly(-lactide) and their evaluation in vitro. Int. J. Pharm. 185(1), 93-101 (1999).

174 He G, Ma LL, Pan J, Venkatraman S: $\mathrm{ABA}$ and $\mathrm{BAB}$ type triblock copolymers of PEG and PLA: a comparative study of drug release properties and "stealth" particle characteristics. Int. J. Pharm. 334(1-2), 48-55 (2007).

175 Redhead HM, Davis SS, Illum L: Drug delivery in poly(lactide-co-glycolide) nanoparticles surface modified with poloxamer 407 and poloxamine 908: in vitro characterisation and in vivo evaluation. J. Control. Release 70 (3), 353-363 (2001).

176 Metselaar JM, Bruin P, de Boer LW et al.: A novel family of L-amino acid-based biodegradable polymer-lipid conjugates for the development of long-circulating liposomes with effective drug-targeting capacity. Bioconjug. Chem. 14(6), 1156-1164 (2003).

177 Woodle MC, Engbers CM, Zalipsky S: New amphipatic polymer-lipid conjugates forming long-circulating reticuloendothelial system-evading liposomes. Bioconjug. Chem. 5(6), 493-496 (1994)

178 Torchilin VP, Shtilman MI, Trubetskoy VS, Whiteman K, Milstein AM: Amphiphilic vinyl polymers effectively prolong liposome circulation time in vivo. Biochim. Biophys. Acta 1195(1), 181-184 (1994). 
179 Torchilin VP, Trubetskoy VS, Whiteman KR, Caliceti P, Ferruti P, Veronese FM: New synthetic amphiphilic polymers for steric protection of liposomes in vivo. J. Pharm. Sci. 84(9), 1049-1053 (1995).

180 Jeong YI, Jin SG, Kim IY et al.: Doxorubicinincorporated nanoparticles composed of poly(ethylene glycol)-grafted carboxymethyl chitosan and antitumor activity against glioma cells in vitro. Colloids Surf. B. Biointerfaces 79(1), 149-155 (2010).

181 Chung YI, Kim JC, Kim YH et al.: The effect of suBace functionalization of PLGA nanopalicles by heparin- or chitosan- 